\title{
Common mystical themes of the spiritual Masnavi of Ru- mi and Golshan Raz by Sheikh Mahmoud Shabestari
}

\section{Temas místicos comunes del Masnavi espiritual de Rumi y Golshan Raz por Sheikh Mahmoud Shabestari}

\author{
Saeedeh Ghadmalsaltani* \\ Islamic Azad University, Neishabur Branch, Iran. \\ Mahboubeh Zia Khodadadian \\ Islamic Azad University, Neishabur Branch, Iran. \\ Faramarz Abbasi \\ Islamic Azad University, Neishabur Branch, Iran. \\ Mehdi Nowruz \\ Islamic Azad University, Neishabur Branch, Iran.
}

Received 06-14-20 Revised 08-10-20 Accepted 09-01-20 On line 09-30-20

*Correspondence

Email: saeideghadamsoltany@gmail.com
Cite as:

\footnotetext{
Ghadmalsaltani, S., Zia Khodadadian, M., Abbasi, F., \& Nowruz, M. (2020). Metacognitive Awareness Instruction: A Mixed Method Study on High School EFL Learners' Writing Development. Propósitos y Representaciones, 8 (SPE3), e760. Doi: http://dx.doi.org/10.20511/pyr2020.v8nSPE3.760
} 


\section{Summary}

There are many pure mystical themes and ideas in the thoughts of Rumi Jalaluddin Mohammad and Sheikh Mahmoud Shabestari. The main purpose of this research is to study the common themes in Rumi and Golshan Raz Shabestari's Masnavi and the sub-objectives are to study the dimensions of Shabestari's influence and follow-up on mystical issues and to study intellectual differences. Rumi and Shabestari and reviewing its arguments and comparing the quality of methods of expressing mystical issues in Masnavi and Golshan Raz. The present study is of a fundamental type. The research method of this research is descriptive-analytical and the results are library. The method of data collection was through recording and taking notes from reliable sources. The results of this research show that Rumi and Shabestari in many cases revealed the same mystical themes in Masnavi and Golshan. Common themes in Masnavi and Golshan Raz are the unity of existence and the multiplicity of existence, existence is of divine light, both worlds are the manifestation of the appearance of God; The veil of the human way, the imaginary of the universe, the loving look at God. The science of religion, distance from oneself, the effects of divine manifestation, the discredit of the world, etc.

Keywords: Sufism, Rumi, Mahmoud Shabestari, Golshan Raz

\section{Resumen}

Resumen Hay muchos temas e ideas puramente místicos en los pensamientos de Rumi Jalaluddin Mohammad y Sheikh Mahmoud Shabestari. El propósito principal de esta investigación es estudiar los temas comunes en Masnavi de Rumi y Golshan Raz Shabestari y los subobjetivos son estudiar las dimensiones de la influencia de Shabestari y el seguimiento de los problemas místicos y estudiar las diferencias intelectuales. Rumi y Shabestari y revisando sus argumentos y comparando la calidad de los métodos para expresar problemas místicos en Masnavi y Golshan Raz. El presente estudio es de tipo fundamental. El método de investigación de esta investigación es descriptivo-analítico y los resultados son de biblioteca. El método de recopilación de datos consistió en registrar y tomar notas de fuentes confiables. Los resultados de esta investigación muestran que Rumi y Shabestari en muchos casos revelaron los mismos temas místicos en Masnavi y Golshan. Los temas comunes en Masnavi y Golshan Raz son la unidad de la existencia y la multiplicidad de la existencia, la existencia es de luz divina, ambos mundos son la manifestación de la aparición de Dios; El velo del camino humano, el imaginario del universo, la mirada amorosa a Dios. La ciencia de la religión, la distancia de uno mismo, los efectos de la manifestación divina, el descrédito del mundo, etc.

Palabras clave: Sufismo, Rumi, Mahmoud Shabestari, Golshan Raz

\section{Introduction}

The main issue of the present study is to study the common mystical themes of Rumi's Masnavi with Golshan Raz by Sheikh Mahmoud Shabestari and to find the content and thematic similarities between Masnavi Manavi and Golshan Raz Shabestari. The similar social context in the time of Rumi and Shabestari, as well as the close epistemological, intuitive and precise experiences of Golshan Raz and his influence on Masnavi, lead us to the definite conclusion that the Sheikh's view of Rumi as an intellectual model have been. In this study, "common mystical themes" is known as an independent variable. 
The method of expressing mystical issues in Masnavi is mostly based on mentioning various anecdotes. also; The allegorical aspects of this work seem outstanding. In Golshan Raz, Shabestari uses the question and answer technique and the anecdotes are not there. Also, the frequency of allegory in this work is less than Masnavi. The description of the subjects in Golshan Raz is much shorter than Masnavi, which is due to the large volume of Rumi's work. Shabestari is quite obvious.

The importance and necessity of Rumi and Shabestari's research are considered as two currents in the field of Islamic mysticism. They have explained many humanizing teachings in their works with their high spiritual intelligence; Therefore, when the poems and writings of these two are examined and explored, it is possible to obtain useful moral, epistemological and religious points. In other words, the teachings expressed by them can be retold in modern language to the people of this period. The result of this effort is to increase the quality of life of the people and to raise their consciousness and cognition in relation to themselves, God and society. Another point that confirms the importance and necessity of the present research is that the degree of influence of Sheikh Shabestari from Rumi is revealed and this achievement is another seal of approval on the character of Rumi and

\section{Research background}

Mal Mohsen Feyz Kashani has a book called "Masnavi Mysticism" which Mehdi Ansari Qomi has mentioned in its introduction: If one wants to research Rumi's mystical thoughts, perhaps the best way is to analyze the generalities of Shams. But if the aim is to know his perceptions of life and religion, the study of his sonnets will not yield any results. For this purpose, Masnavi is a better choice. Rumi in teaching this work intends to teach and advise and ways to reach

It teaches God and the knowledge of the soul. Some believe that Rumi does not fit into the form of Muhammad al-Ghazali's Sufism and say: His Masnavi sometimes even with Sufi principles such as "hatred of the world and love of God", "self-destruction and survival in God" and creation of morals. Is also in conflict. On the contrary, Masnavi is more concerned with issues such as the "religious life of the soul" and the "desire of the soul to unite with the truth." But carefully in the concepts of Masnavi, it is clear that Rumi had thoughts beyond everything, in other words, it was total peace, and if there are differences between his behavior and thought There are people like Mohammad Ghazali, but he is not in conflict with it. Masnavi is selected without order from all the philosophical and theological ideas of the Islamic world from the beginning to the seventh century AH. Rumi, everything in every device.

An intellectual has achieved, he has chosen. The discipline that connects these unrelated points,Masnavi stories. Bakhshali Ghanbari in his article entitled "Bibian's speech; A study of Rumi's mystical experiences. In Masnavi, he points out that Rumi's life was full of all kinds of mystical experiences, some of which are reflected in his works, including the spiritual Masnavi, but what is mentioned in this work is the expression of experiences in the language of others. This may raise the suspicion that Rumi may have missed no mystical experience. The subtle point is to note that Rumi has seen himself in the mirror of others, this suspicion will be removed. However, in his article entitled "A Brief Overview of the Mystical Thoughts of Maulana Jalaluddin Rumi", he concluded that Rumi always encourages the acquisition of science and art in Masnavi and Diwan Kabir. He is a useful scientist 
He knows that it originates from the heart and mental states of the perfect man and guides man to understand the divine truth. Ali Tajdini in his article entitled "Mystical language in Rumi's thought" has concluded that the language of the poet is the language of revelation and the language of art. Revelation, mysticism and art are related to each other. Hence, Rumi believes that among the sects of conduct, none of the philosophers, theologians and mystics are as close to the text and language of religion as mystics.

He says that the God who is described in Rumi's poem and has a perfect relationship with his optimistic and hopeful mood and spirits, is total mercy and absolute grace. The divine prophets, too, are in fact heralds of the heavenly feast. The content of their mission and law is also taste and mood and life. Mohammad Kazem Yousefpour and the author of a part of his article entitled "Comparative study of the element of light in Masnavi with the most important mystical works of Persian literature" have come to the conclusion that Rumi relies more on the epistemological aspects of the element of light.

He has dealt with the Qur'an and Shari'a, and his view of the element of light and its functions, including Sufi idioms such as Ali ibn Uthman Hojviri and Abu al-Qasim al-Qashiri, and ontological and epistemological considerations such as the judges of Hamedani and Ahmad al-Ghazali, as well as a structured and coherent system of thought. Ibn Arabi and his followers are different. Although Rumi refers to the epistemological features and values of the element of light from various aspects, but from an ontological point of view, it does not go beyond the framework of the Qur'an and Hadith. Abdul Hakim has reached this conclusion in his book entitled "Rumi's Mysticism"

Masnavi is an effective and wonderful spiritual concoction that Rumi has arranged for the treatment of souls and souls and in its combination has made wonderful uses of all the spiritual components of Islamic thought. In his work, he is both a mystic, a sage, a jurist and a storyteller. He is both serious and grumpy, and he is funny and smiling, he is both a Sufi of the monastery and a comrade of Mushko and Khargah, but above all, he is a thinker who strives to unravel the mysteries of creation and in this endeavor he commented on all his leaders and Where he sees their opinion as incomplete, he does not stop protesting and expressing his opposition. In the case of Golshan Raz, Mahmoud Fazilat (2008) examined the mystery of existence in Golshan Raz Shabestari. Lily Abbasi Montazeri (2011) in an article entitled The Study of the Principle of Knowledge and Theology from Rumi's Viewpoint in Masnavi In Golshan-e-Raz, Touraj Aqali (2010) in a study called Golshan-e-Raz's aesthetics showed that Sheikh Mahmoud Shabestari recognized metaphor as a suitable tool for expressing imaginary similarities between abstract concepts and objective phenomena and used it extensively. Malik Shoaee (2012) In a study called Shabestari and the idea of the unity of existence in Golshan Raz, they showed that Shabestari tried to introduce concepts in the new design. The beginning of creation is also unusual, this article has been able to. Find and introduce the ideas of existential unity hidden in all 15 or 17 unanswered questions of Sheikh Shabestar. Rajab Tohidian and Hadi Khadivar (2010) also conducted a study called Intuitive Knowledge and Argumentation in Golshan Raz by Sheikh Mahmoud Shabestari. Also, Abdolhossein Latifi (2016). 


\section{Mystical themes of Masnavi and Golshan Raz}

Divine love Love has a special place in the discussion of mysticism, and of course, in this category, there is always talk of true love, that is, divine love. (Previous and others.) 1392 True love is the love of God and the saints of God.

The valley is one of the valleys of annihilation and it is the neck from which the houses of the annihilation of actions and attributes can be poured. Live love is in the psyche and in the eyes of every breath. Choose the love that the prophets found in his love Kar and Kia (Ibid., Verses) 218-220 In these verses, Rumi points to the non-repetition of true love. Lover according to the existential talent of the lover of every moment. It comes in a way and it is not in a way that it causes boredom. (Nosrati et al., 2013)

Love and mania are the religion of Rumi and he does not adhere to any religion to this end, so he said that love has plundered everything and remains itself, so anyone who has little acquaintance with this great Hearing his name will evoke his passion and mania. Love is a divine attribute that, when the bondage capacity finds its acceptance by breaking the material and intimate boundaries of itself and transforms its whole existence as if it had been reborn, a birth from the mother of love to nurture and nurture the mystic. It is believed that love is a divine attribute and no human being can understand its truth. Only by falling in love can one taste it, but never.

It is indescribable, especially since love (as well as the beloved) is sometimes found and sometimes hidden. Example of love, I did not find secret and hidden like you. Nevertheless, among the attributes that Pir Balkh considered for love, it can be said: Love is a fire that the eternal witness falls as a blessing on the souls of the enthusiasts and creates a hole for them to escape from the prison of the world and flies them to the cage May the heavens perish and may the attribute survive. Despite all the name that Rumi explicitly

\section{Ask me for love}

Because the pen did not rush into writing, because it fell in love, the pen split on itself (the first book of Masnavi,) 114 Sheikh Rumi is of the opinion that the description of love cannot be written on paper with a pen and the state of love can be interpreted. And the greatness of love speaks of the splitting of the pen when he intends to write a description of love. In all mystical schools, including Islamic mysticism, love is the most fundamental and important issue. In Sufism, mysticism is based on love and love is the basis of life and survival of the creatures of the universe, and the movement of the earth and the sky. All beings depend on the existence of love. The late Professor Ghani writes: The product of the mystic belief in the subject of love and affection is that love is a divine instinct.

And it is the heavenly inspiration around which man can know himself and be aware of his destiny. Whatever I say, I describe and express love because I am ashamed of it (Daftar I, Masnavi, 112) Although love is the most fundamental mystical issue, mystics have expressed their inability to describe it and have said: Whoever defines love It is unknown. Rumi, in order to emphasize the infinity of love, says this and refers to the indescribability of love, which if described and described as love, although it is very beautiful, is still a particle.

There is little truth in love. 
Description of my love to say that I will spend a hundred resurrections and I will not finish it (Masnavi, the fifth book), 2189

Sheikh Rumi points to the greatness and infinite limit of love, because infinity does not fit in time, and emphasizes that the definition of love is great and infinite, and cannot be limited in time. Be specific. (Karim Zamani, 1382).

No one should be in love with Joe, who was not a lover, seek him, because in this heart of electricity, love is sought, in the heart of friendship, the field that is, in your heart, the love of truth, because it became two, I doubt the truth, your love(The third book of Masnavi,) 4393 Rumi considers love as the head of creation and the cause of the rest of the world and current in the fabric of the world. Every movement and activity is rooted in eternal love. Love, which is one of the attributes of God (Masnavi) 971/6, is like the brain and the world is like skin (Diwan) 22225 / All beings benefit from divine love: If you did not love this sky, you would not purify his chest.

And if you did not love the sun, you would not be in his beauty. Land and mountains, if you do not love Andy, you will not love the heart of both plants. If the sea, love, if you were not, you would have run away somewhere (Divan Ghazaliat Shams)

\section{Without love, science would not have been created}

If you were not pure love, when would you give existence to the heavens? (Fifth book of Masnavi,) 2739 In this, man has a special relationship with God and love between him and God is the peak of love. Man is the only being to whom God openly expresses his love in the word of revelation: God will soon be an ethnic group.

He says that he loves them and they love him (Yahbham and Yahbuna). They are kind and humble to the believers, and hard on the disbelievers (Ma'ida). 54/5 In this verse, which is highly cited by Muslim mystics, including Rumi, the love of God in It is located for the first time in the fourth book of Masnavi (2921-28). This mutual love has been spoken of. God reveals to Moses that he loves him: He said: I love Moses by the revelation of the heart of God, which I have chosen. (Rumi ,: 1383) 126-127 Rumi tries to manifest the love between the Creator and the creature in order to replace the divine love and sense of security in the fear of God in man Rumi considers divine love as a means to reach God because he lives through love Plato says in the treatise on the feast: Love is the mediator between man and the gods and fills the gap between them (R. K. Kaviani, 1349, c: 1.) 434 But Rumi says that love not only fills the gap between the lover and the beloved but also The lover becomes mortal in the beloved and unites with Emma. Rumi has explained this in a subtle anecdote that begins with the verse 1999 of the fifth book. The insane goes to the cupper. As soon as his gaze falls on the sharp razor of cupping, Wade trembles because Jamtgar notices the insane fear of insanity. Here is Rumi from the language.

Majnoon expresses the issue of the union of lover and beloved as follows:

Majnoon said: I am not afraid of my patience, it is more than a heavy mountain I love you so much, I love you I get wounds

Lick of Lily My existence's worship of this oyster is full of its attributes 
I am afraid of corruption, if you intend to bite a woman suddenly into a lily, the intellect that she is a clear heart is no difference between Lily and me.

(Fifth book of Masnavi,) 2015-2019 It can be said that the smell of burnt soul and the pain of love from the poems of Rumi reaches the nostrils of every singer and listener and

Impressed and fascinated. (God and others,) 1391

From the stars of the sky, come from constant and disgraced from the other, that star is taft on your Saturn (Ghazal 142, verse) 8 Love in Masnavi is a compound that frees man from selfishness and reaches the land of the beloved to the point where there is no difference between lover and beloved Was. (Faridi et al., 2014) Love is known as one of the names of God and In the following verses, Rumi has considered love as one of the attributes of God: Fear is not a hair in the face of love, including the sacrifice in the cult of love

Love is a description of God, but that fear is a description of an afflicted servant

Because you read Yahbun in Nabi with Yahbham in the article

So love is not a description of the righteous, love was not a description of God, dear

What is the description of the right? Where is the queue? What is the description of the incident?

The description of my love is to say that a hundred resurrections will pass and it will be unfinished

Love is five hundred full and every fairy from the top of the throne to the underworld

(Masnavi, Fifth Book, from verse 2184 to) 2191 From the point of view of Master Mostafa Malekian, this question arises: All I am saying is that while Rumi believes that if you want to become moral, you must fall in love, we can not understand that we must fall in love, ie What should we wash? You mean, like, erotic love, eh? Or should we find love from the category of filia or should we find love from the genus Agape? And so far none of the scholars have been able to determine what this love is. But we constantly talk about the fact that Rumi is the ring of lovers and talks about love from the beginning to the end. What is really the truth of the love that Rumi is talking about? So my question is what is the love that turns immoral people into moral people and has such an art, and this love

How can it be studied and acquired? Therefore, it is necessary to recognize their different meanings. Because sharing the word is always a bandit and keeps man away from the truth. (Masnavi, d.) 646-653 / 6 In the same way, it is possible that the word love is used many times in a specific text such as Masnavi or Divan-e Shams, but in all cases a specific meaning is not necessarily intended from it.

Therefore, it is necessary to carefully separate all the different meanings of the word love and pay attention to their uses. After we have separated the different meanings of love, then it becomes clear that:

1) Some types of love are recommended and others are not. Some types of love can be given to humans. Recommended, but some other loves are basically not recommended.

2) Some types of love are perfect and transcendent, so some other loves not only help a person grow. They do not, but they also prepare the ground for his moral decline.

3) Some loves are from the category of feelings and emotions and have nothing to do with human intellect and will, and some other types of love. They are from the category of intellect and will and do not pay attention to emotions.

4) Some loves belong only to human beings and others also belong to things, ideas and systems.

5) In some loves, separation means separation, but in some other types of love, there is no such thing as separation. And there is no separation. 
6) Some loves belong to only one person and that is enough, but in some types of love, it is possible for both human beings and even. Love each other creatures.

7) In some loves you can not and should not love yourself, but in some other loves the condition of any kind of love, Love yourself.

8) In some types of love, God can also belong to love, but not in others. 9) In some such a thing is not possible. These are some of the most important topics that can be talked about carefully after recognizing the different types of love. It seems that love can be divided into three general types in terms of types of lovers (1: Divine love) 2 Cosmic love) 3 Human love.

The meaning of this division is that God may be in love, the creatures of the world may be in love, and man may be in love, so in a general division, love can be divided into three types. Each of these three types of love according to.

Their belongings can be divided into smaller species:

1) Love of God, self, is divided into three smaller types: love of self, self love of the creatures of the world, God's love for human beings in particular.

2) Cosmic love can also be divided into two smaller types: the love of creatures for God and the love of every creature for Pairs (tension between creatures.)

3) Human love can also be divided into four smaller types according to the four types of relationships that humans have: human love for God, love for the homeland and love for natural phenomena such as mountains and the sea and forests and flowers and animals. Human love for other human beings, which is itself divided into nine smaller types: love from blood and race. Love due to sexual instinct, love due to homosexuality, love between man and woman (for the purpose of marriage), erotic love (love based on the beauty of friendship), romantic love, friendship, love due to the existence of a common value such as love Religions

And the homeland and the party and the same sex, love for the king, an example of an ideal, like love for an example of the ideal of freedom. Or truth-seeking, agape love. Therefore, at least 18 types of love can be distinguished from each other. It seems that Of the eighteen types of love mentioned above, Mawlana has spoken of more than 5 types: 1) God's love for all beings in general and for human beings in particular, 2) Creatures' love for God and the tension between beings) 3 Human love To God) 4 Mowlana love to the saints of God) 5 Man's love to other human beings unconditionally (Agapai love.) Besides. Rumi in some of his poems, such as the sonnet in question, considers love as one of the names of God, so in Rumi's works at least with.

We encounter six different models of love and each of these models has its own characteristics. (Quoted by Shahbari,1395 From this important point, four completely clear results are obtained:

1) The subjugation of the lover against love

2) The psychological unity of the lover) 3 The unity of love and the lover

4) The lover reaches the position of witness

Sama Sama in the word means listening, dancing and ecstasy, but in the term of mystics, Sama means singing a mystical song or song by the Qawwal or Qawalan and the listeners are delighted in the meetings. The source of this hearing is nothing but love, a love that 
kills like a fire and man can not stand against it, so he melts in it and perishes, and when he hears the name of his friend, his heart trembles and joy and happiness envelop him.

Takes. (Quoted from previous and others,) 1392, (Heidarkhani,: 1374.) 21 It can be said that the Islamic world can be divided into at least three distinct groups based on stance against hearing.

Kurdish: a) Opponents of hearing, those in favor of hearing and those in favor of hearing conditionally. Rumi does not agree with any hearing. In his opinion, listening is permissible in special circumstances and for certain people.

According to Rumi, the terms and conditions of hearing are inner cleansing. Therefore, the important condition of hearing is purification and cultivation of the soul. Such a person finds the light and love of God through his hearing and dancing, and with more intensity, speed and strength towards God.

Behavior Dance is beneficial for someone who breaks himself and restrains his lust. Dance where you break yourself, remove the cotton from the beard of lust. Dance and dance on the field, dance in the blood of men. Let them dance with their hands, let them dance with their hands because of their imperfections. Its proponents beat from within, the seas clap in their revolt. You can see the leaves on the branches and the palms of women on each ear

Listen to the joke of lies and lies! To see the city of John with light(Masnavi, third book, from verse 95 to.) The unity of existence One of the most fundamental topics in the field of mysticism and philosophy is the issue of the unity of existence, which has always been the subject of discussion and study by scholars and followers of the path, so that the two teachings of unity of existence and perfect man as pillars and axes. The teachings of the Sufis are well known. (Nosrati and others,) 1392, (Nasr,: 1382.). From Rumi's point of view, the deep and subtle points of mysticism and especially the issue of the unity of existence are like sharp swords, which cannot be confronted without providing a shield of solid perception and understanding. So, is there a human being who understands the exact and deep points? , You do not have the necessary talent and ability to understand, you should not go to it

Says:

Points such as the fact that you do not have a sharp-edged razor blade in the shield, backwardness (first book, b 691) He believes that beings were pure non-beings that God created them with His perfect power and again at the end of their life returns them to non-existence. So the existence of beings is between two non-beings.

Of course, his existence is credible and untrue. Therefore, he says: he has no eyes or ears on the lack of things, because he sang Fasoon, it also comes to a boil.

Because of his charm, absences soon hang in the balance. Again, he chanted on the charming creature and soon drove two horses in the absence (Ibid., Verses 1450) 1448- In another verse of Rumi's Masnavi, he considers himself extinct, non-existent, and existent. His view in this regard is existential unity. Excellence from Jealousy does not reveal it. 
What do we mean by words? Proof and denial I am not proof, I am self-denial. I found someone in Naxi, so I found someone in Naxi (Ibid., Verses 1735) 1734-

This view of existential unity is closely related to the annihilation of Sufism, because the perception of the truth of the unity of existence in its comprehensive meaning requires attaining the status and rank of annihilation and the connection of the mystic essence with the true famous of the Almighty. Truth is the same attitude of existential unity. This is not the existence that he proposes is not non-existence, but the very existence and origin of the existence of the universe and man. In this Rumi's speech, there is a kind of verbal paradox because what he proposes as human existence Truth is mere non-existence, and what it refers to as non-existence is in fact the origin of existence, that is, truth

Achieving this non-existence means the blossoming of the seedlings of human existence while the capitals of human virtual existence. It is constantly declining and disappearing.

Therefore, he says:

Return from the present, towards the non-existence of the rabbinic and rabbinic student This lack is an income, this lack is a source of expense for him, this existence is more or less (Book 2, verses 689).

Because it bends in it and the dialect: Qom says from Tarab: I am bent, Al-Talam. It has the color of fire except iron (Book 2, verses 1347)

The bending of dyeing in the house of 1346 is a sign of the degree of unity. The Almighty falls and his vision is united and his heart is united. Turns. Rumi in the house of 1347 and other places such as the superficialities of the Sufis as our great glory

The status of Masnavi is the claims of An-Haq and, and Hawal-Haq actually interprets the meaning of An-Haq as Naghz. It distinguishes Hallaj from Pharaoh's claim that Pharaoh's claim was the result of God's denial and Hallaj's statement. Due to annihilation and immersion in the essence of oneness: Pharaoh said, "I am right." The post said, "Mansoori, I am right, and it is the curse of the people behind it, and it is the mercy of the people, O beloved." (Homayi, 1356, vol. 1, pp. 231).

When these great men say: They do not consider themselves the narrator of this speech, but the narrator and the narrator of the truth. They are counting. It means that it is the right that has been blown in the throat of their existence and there is a voice, Hu al-Haqq has sung the truth.

Therefore, the meaning of our Glory is the greatest honor. And there is no other. Sheikh Mahmoud Shabestari begins his speech with the affairs of existential unity: he saw the world as a credit matter that has become one in Sari numbers. The world was created and commanded by the soul, which was returned when it came. Originally gathered objects all became one thing hidden and found. The world of creation and matter became one here, bring one and became very few Shabestari because Ibn Arabi believes that God is the absolute eternal eternal existence, there is nothing but Him and the whole existence. 
It is proven to researchers that there is no other being in existence except God. Our existence also depends on him. (Conquests, vol: 1) 363 There is no need for another reason to prove the existence of God. Existence is a single truth and is free from multiplicity. What we perceive as plurals by our senses are in fact forms of attributes. Divine are manifested or illusions are made and paid for by reason and there is no difference between creator and creature. (Radial,) 1395

Existence in the word means existence and in Sufi terms ecstasy without referring to ecstasy, since monotheism means believing in the oneness of the Almighty, and as God says in the Holy Qur'an: The essence of truth and the belief in the oneness of truth in his actions. Thus, unity of existence is rooted in monotheism, and mystics believe that the mere truth, everything, and everything is the truth, which will require unity in plurality and plurality in unity. According to mystics and Sufis, truth is the existence of a principle and a collective origin Effects. According to Maulana, the world of unity is not the world of determination and plurality, and if we look at the world of plurality, only one truth will remain. The human soul is inherently free from the world of multiplicity, and if these differences and additions are abolished and man is immersed in the existence of a single soul, everything becomes one. He says that if the determination of a man and a woman disappears, and in order

\section{Designations and pluralities}

Unity, unite and find the status of absolute unity, that indefinite unity of yours, because when Abolish only you who will exist.

Mystics consider the existential unity of the universe with all its essential multiplicity and diversity as manifestations of a single point and call it the unity of existence. Shabestari has also explained the argument for the unity of existence in Golshan Raz. Everywhere in this poem, he describes and analyzes the theory of unity in plurality. Therefore, Golshan Raz poem can be considered as a thematic abstract of all books of poetry and prose that have been written and written about mysticism and especially the unity of existence until the seventh century.

Traces of the thought of Ibn Arabi, Sanai, Attar and Rumi about the unity of existence can be found in this system. However, Shabestari's special style and language distinguish him from the aforementioned works, which should be studied and analyzed instead. The validity of the determinations and the originality of the existence of the unit and the attention of the mystic to the knowledge of the absolute existence and its manifestation in the mirror of the manifestations sometimes make Shabestari non-knowledgeable. In his view, the concept of nonexistence is also like a single being, and these pluralities, which are also like a single existence from the concept of non-existence, and these pluralities that play a role in the concept of nonexistence in our minds, are due to the relation that non-existence exists. Mansour Halj also expresses the unity of existence, just as Anna al-Tree of Moses has the same meaning and content. But the manifestations, which are in fact the same beings of the universe, should not be unique and existent.

The existence of creation and multiplicity is in the manifestation, not what it seems to be the same (Golshan Raz,) 46 (Fazilat, 1387). Survival and annihilation Survival is the opposite of annihilation. In Surah Ar-Rahman, verses 26 and 27 of Al-Ali 17 and Mu'min 16 and Qasas 88 are mentioned. According to mystics, the beginning is the journey for the people, 
which is the result of death from femininity, life and the permanence of the morality of the clergy. (Sajjadi, 1370) 198 Rumi believes that human beings are death and return at any moment. The catastrophe and the survival of human life have arisen from those who will not arise until it perishes:

So, every moment is death and return for you. Mustafa said that the world is for you Every soul becomes new to the world and we are unaware of being renewed in survival (Rumi,: 1989) $1 / 141$

The poet has made human life like a stream of water in which the flow of water seems to be permanent but in the world it has a temporary meaning: life reaches like a nono atmosphere and continues in the body.

It was formed from a continuous sharpness because its evil one got a sharp edge

Shake the horn of fire In view of the fire is too long

This long-term sharpness of the craft speeds up the craft

(Rumi, 1989,) 144/1

Death and survival, in other words, old and new, exist throughout the material, vegetable, human and animal worlds:

In the human being, the soul and the soul come from the unseen like flowing water (Rumi, 1989,) 2222/1

Mortality and survival are necessary for each other so that the seeker does not perish in the truth, and as a result, the world of survival does not attain: Except for the relatively extinct Iqnova

In proportion to the attributes of the right of annihilation, in fact, he survived in annihilation (Rumi) 1368/4/3968

The death of the seeker is the reason for his survival and this rule that causes perfection is also valid in the world of raw materials, plants and animals:

Al-Shadi Pahlavi Al-Khangir It is a wonder that he is both a prisoner and an emir

And: You came from the day you came to give fire or wind or bad earth (Rumi,) 2947/4/1368

If you were in that state, when did you survive this promotion?

Also, up to one hundred thousand nuclei after each other

You found these remnants of annihilation, why did you escape from its annihilation?

Because the second is better than the first, so worship the mortal and the converter (Rumi,) $789 / 5 / 1111368$

Mawlana has said about human annihilation and survival according to the divine attributes of a dervishes: He said that there is no dervishes in the world.

He said: It is not due to the survival of his essence that he has been described as $\mathrm{Hu}$

Because the tongue of the candle is not in the sun, it is in the account

It is his nature that if you do not burn cotton, it is evil

It is not clear that he has not made you, the sun has destroyed him (Rumi,)

Inspired by Surah Qasas, verse 88 in the Holy Qur'an, he says: Also, seek God when God comes, seeker of God.

Although that connection is in survival, the first link is in survival

Who is the mind that is the head of the whole object of the Hulk of the face (Rumi) 4658/3/1368

the most desperate tendencies of his algebra, he uses the negation, the proof, the disappearance, and the emergence of the absolute constraint, and 
Says:

Absolutely, that song was from Shah, although it was from Abdullah's throat. He said I am your tongue and your eyes I am your senses and I am your pleasure and anger. When you hear and do not see in your head, what is the place of the owner of your head (Rumi,) $1936 / 1 / 1368$.

Annihilation in Masnavi is directly related to the denial of the will of the slave and the proof of the will of the right, which means that whenever the servant of his will submits to the will of the Almighty and accepts whatever God has decreed for him with complete satisfaction, he will be annihilated. Then, to the extent that the will of Abd Rang Bazd, the will of the will of the right becomes more prominent, to the extent that no trace or color of the will of the servant remains, and this is where the desired annihilation of Sufism and Rumi takes place. In the above verses, Rumi has considered himself as a harpist and God as a harbinger because of his allegory. If a voice arises from the clutches of his being, in the sense that he is a mortal, this sound that arises from the clutches of his being is also from the right side. Rumi calls himself a reed because of the allegory and calls God a female reed and believes that if a spiritual voice arises from his existence in the hearing sometimes, this voice is from the Almighty who is the creator of sounds. He also considered his existence as a mountain in which the unseen voices of the Almighty are reflected. These unseen voices hit the mountain of Rumi's existence and then, with a curved journey, he returned to his mine and source, which is the divine world.

Being mortal in Masnavi is equal to the lack of strength and intensity of the servant's weakness; From this point of view, the clause that feels more humiliated and has reached the level of humiliation and poverty is at the level of annihilation. Such a person is like a lion on the screen who goes up and down with the wind and has absolutely no control over himself. (Nosrati et al., 2013) Fana in Masnavi takes man away from him. It reaches and passes through it until it reaches the annihilation of the people and there is nothing left but the essence of Lamzli. (Faridi et al., 2014)

Mawlana also considers himself in mystical annihilation, which has made him unconscious:

The whole thing is said to be non-mufiq, which is obligatory and possessive. What can I say? A rug is not conscious. Description of the helper who is not his helper (Rumi) 128-130 / 1/1369 I am perishing mystically. You bother me because I have lost my comprehension and I can not praise. Whatever a person says in a state of unconsciousness, that word cannot be understood, and if someone wants to understand those words, he does not deserve such a state. Therefore, praising is a sign of righteousness and vigilance, and whoever is unconscious and immersed, his customs and works become mortal and perishable in his manifestation, and his expression is interrupted (Forouzanfar, 1998:). And this annihilation

Leads man to true survival:

He will not perish until he finds anyone in the court of Kobria. Although that connection is between survival and survival, the lake is at the beginning of annihilation (Molavi,: 1369) 232-233 / 6 The seeker in the course of perfection, every moment goes through a part of the longitudinal limits of existence and because each time is complete in Is the lower 
stage in which mortal a In this position of politeness and politeness claim from him. It is taken away and such a seeker cannot be called rude, but he has reached the highest position of literature: he was anesthetized in front of a deer lion.

This incomplete analogy is the work of the Lord of boiling love. The pulse of the lover of rudeness on the jihad puts itself in the cup of the city. No one is more rude. No one in the world is more polite. No one in secret is in proportion to the chosen harmony between these two anti-polite and rude people.

Be rude when you look at the appearance of his love affair. Because looking inwardly, where is the claim against him and the claim before him is the king of death (Malmeli, 2008).

\section{Manifestation of the right}

Manifestation in the word means to reveal and enlighten and manifest. In Persian literature, the manifestation of allusion to light. It is God who, after going through the houses and attaining the status of annihilation for the people, is achieved. The idiomatic meaning of manifestation in according to the mystics, it is the absolute essence of the Almighty and His perfection that shines on the hearts of the seekers after many journeys and behaviors, and sometimes the irony of the appearance of divine light in the mountain is where Moses fainted from it. In Christianity, manifestation is the name of a Christian festival that is held on the sixth of January every year, and on this day John the Baptist baptizes Jesus Christ, and the Holy Spirit appears on their heads in the form of a dove, and this day at sunrise.

It is famous. (Dad, pp.) 115-116 The issue of manifestation and emergence of truth in the levels of existence in general and in the perfect man in particular, through the union of appearance and manifestation is one of the sensitive positions and very precise points of Rumi's way of understanding the truth For most people, even the literate educated class is difficult, and because, as Rumi puts it, wisdom perceptions and the narrow-mindedness of ordinary minds do not have the capacity to understand that mystical joke and the capacity to comprehend that heavenly truth, it may slip into delusion. The right is manifested in the human body and human existence is connected to the right and united with it. This union has taken place, not through intrinsic personal solution and unity, but through optical unity and the union of dignity (Homayi).

And the annihilation of darkness has taken place in the light and decay of character and separation from determination from existence. Rumi in a cosmological approach to knowing the world and the levels of existence, also follows the ideas and theories of Ibn Arabi and at the same time presents innovative thoughts about the manifestation of truth in the levels of the world, in this part to some mystical poems and We point to him wisely. In the third book of Masnavi Manavi (4129-4132) he says:

What he said to the flower made him laugh with my heart, and he did it a hundred times, what he did, he straightened his head and height, and what he ate from Narges and Nasrin, what he made of straw, sweet soul and heart, and what he found in the soil, Such a turn made the face rosy and flowery. And what Kahn gave, Zar Jafari gave the language a hundred charms Rumi in these poems claims that God attributes his beauty to all forms of physical and spiritual beauty. 
The show gives a gift to his lover. (Nicholson, pp.) 1306-1307 or Rumi says in the first book:

Reason is hidden and the universal appearance of our face is not a wave, or from him (1112). The poet means in this verse that just as the intellect is hidden and the world of the face is apparent, so the essence of Hazrat Haqq is apparently hidden like the sea and the forms of beings and possibilities are obvious. Mystics have likened definite existence to a wave or moisture and absolute existence to the sea. Because the wave and the moisture are the manifestations and events of the sea and this world of multiplicity is also the manifestation of the Almighty. And one of the wonders of divine dignity is that it appears in secret. (Zamani, p.) 377 Rumi also mentions in the fifth book in verses No. 985-989 about the manifestation of divine beauty in the world that Hazrat Haqq. True unity is manifested in the mirrors of possibilities and the physical beauties that seduce the viewers.

Makes a loan is a description of the spiritual beauty that has been added to the constellations. And it is a ray of eternal goodness that has traveled from the world of meaning and has taken up residence in the earthly body. When that beauty returns to its place except ugliness. And there is no darkness. (Shahidi, p.) 154 In this way, multiplicity exists in the world.

That beauty, power and grace of the art of the sun made this journey. They return because the stars are the light of the sun on the walls. The sun's rays became the place of every dark and black wall. What he did, he made your face dang the sunlight out of tricolor glass

Or in the first office it says:

He said with the body, a verse came to life, he said with the sun until it shone, he (1452) God manifested on the body and made it the owner of the soul and manifested it in the name of light and the sun appeared. According to mystics, God is the manifester whose action is in the form of objects Manifests. In the same office, he says: "He said in the ear of a flower and smiled at him. He said that he rubbed it with stone and insulation."

That is, the Almighty said to Gol Razi and made him smile and happy. And he told the stone a secret and put it in the mine. He turned it into agate. And the man of telling the truth in the ear of a flower is the manifestation of the truth with a gentle name in the flower. (Jafari, 1386).

Silence One of the most important issues in Masnavi and Divan-e Shams is the issue of silence and we should talk a little about it. Silence is one of the forgotten virtues of our time. Here are some tips on talking and silence.

According to Mowlana, we mention:

1) Rumi's nickname has been silent (silence, silence or bending) and there is almost a kind of consensus among. It is seen by scholars.

2) The Three Levels of Silence: As Aldous Huxley quotes the Spanish priest, mystic, and mysticThere are three levels of silence: silence of the mouth, silence of the mind, and silence of the will.

3) Silence is a condition for gaining knowledge: Speaking prevents one from receiving the divine bill and also deprives a person of the lofty knowledge of the heart. Someone who is 
accustomed to talking non-stop and there is no opportunity for silence. It does not bring the gate of its existence closed on divine graces and inspirations.

4) Silence and spiritual experiences: The subject of speech can be issues related to the material world and can be issues related to religious, mystical and romantic experiences. People like Rumi talk about spiritual issues.

They consider it completely useless and rely on at least four types of reasons for this claim: 1. The first reason is that the quantity of expression and language in those areas is completely lame and from the expression, description and communication of experiences. Spiritually incapable. (Masnavi, d112-115).

1. d3013-3015-2 and d) 4620-4624,

2. Confused and confused causes the logic of language to be completely confused and not to be afraid to speak.

3. The third reason that not all human beings have the talent to understand such issues (Masnavi, d. 18/1 and d) 2759-2761 / 1

4. The fourth reason is that the awareness of all people about spiritual issues causes the life of this world to be threatened because the pillar of this world is based on human negligence and negligence causes disruption in the system of life. In some cases, the awakening of human beings must be neglected

To be told. (Masnavi, d) 2066-2070 / 1

5 Silent and eloquent: Now it is time to ask why Rumi, who speaks more than all the mystics and sages about the plagues, has called us to silence. He himself has talked a lot and

Has he revealed spiritual secrets? As we know, Rumi has repented more than 25,000 verses in Masnavi and more than 30,000 verses in Divan-e Shams and has decided not to speak anymore, but we see that his repentance does not take long. And repents. Because in this kind of speaking, there is always the possibility of error and mistake, and also in conscious speaking, there is a kind of veil between man and God, because speaking is a sign.

Is and someone speaks that we are not and only God and that is enough. This is exactly why Rumi, in the stages of mysticism, praises and glorifies God by praising him and actually proves his existence, while perfection. It is to completely subdue one's existence before God: It is wrong to say praise to me, but it is wrong. He is coming, he is not coming, what are you coming to him? Blind and blue (Masnavi, first book, verses) 518-517 Rumi repents of conscious speaking, but when unconsciousness overcomes him and there is no distance between him and God, then the word of God comes out of his mouth. According to Rumi, the real word is to overpower a person, to make him disappear and to leave himself, and to leave no trace of me. There is no word from China that one can and should not repent. This kind of speaking is a natural act of a mystic, just like the smell of giving pleasure, which is a natural act of a flower. And it is not nonsense. In many verses of this noble swing, we do not see any trace of Rumi's character, and Rumi speaks in a state of drunkenness and unconsciousness. Just like a reed whose voice is the same as the reed playing, hence the rhetoric. Rumi is typically the product of his decline of consciousness.

Dr. Shafiei Kadkani (Introduction to Ghazals of Shams Tabriz, p. 107) has written about this: Miand is neither Turkish nor Nashaburi, and for this reason he says that one should speak and sound. He passed and reached the logic of life. In Masnavi and Divan-e Shams, there are verses about the wordless word. 
That the soul of Sarafil and the formal wind that blows late and far away, woe to this distance, if there is no forgiveness, it is enough. Forgiveness is neither Roman, nor Turkish, nor straw.

Neda herself is it, and this is the rest of the voice. He has understood that the call is made of wood, stone, ink and stones

Slave of poetry, I should know that poetry is what you say. Speech is like an arrow and language is like a bow. Words and sounds should be the logic of life. The goat on the other side listens, speechless, hearts. Rumi says the same meaning in Masnavi as follows: The voice that is the essence of every call and song is Turkish, Parsigo and Arabic. What a place for Turks and Tajiks, and the cleverness of every breath comes from him

The issue of thinking is one of the Sufi issues that appears after the introduction of introductory verses in Golshan Raz. In other words, Heravi's first question with which he begins his valuable book is the question of thought. He says:

First of all, I wonder what my thoughts are. What is called thinking? (Shabestari, 2003: 70) 70 In fact, the problem of Sheikh Mahmoud is to explain and clarify the nature of thinking. This is one of the issues that someone like Sheikh Mahmoud is amazed by the truth. It may not be strange for a philosopher to ask this question, but it was asked by a mystic from The behavior is amazing. That is why he says:

Tell me, what was the meaning of Kazin's thinking, I was left in amazement (Ibid., Verse 71). It is interesting that after raising the issue of thinking by Heravi, Sheikh Mahmoud answers the question and says: Thinking is in fact a spiritual behavior from the outside to the inside and from the face to the meaning and soul (Lewisin, 1997: 304)

Asas says with special taste and conscience in Golshan Raz:

Thinking of going wrong The right to see the absolute whole (Shabestari, 1382 Beit) 73 From Shabestari's point of view, thinking means understanding the fact that existence is unique in the nature of God and beyond God, everything is only its manifestation and manifestation. That is, God is a pure being. The signs (verses) of God and His works Creatures are neither like God nor different from Him. According to the Ash'arites, the attributes of God are neither God nor anything but God. The world of Forough Noor Haqdan Haghdan is hidden from him Shabestari in Golshan Raz, after raising the issue of thinking and discussing the views of the master of reason and the companions of discovery, explains the different levels of thinking. Accordingly, he states that thinking that is the condition of seekers is different from thinking that is the condition of wise people. Each of these tribes has a formal and spiritual grace based on their existential possibility and talent. On this basis, it indicates that thinking in the body means names and attributes and The acts of truth are like obedience, but thinking in the essence of Quds, the force of force, is the meaning of sin. Where he says: Thinking is the condition of the way, but in the essence of truth is pure sin. 
Which of our thoughts is the condition of the way was in the essence of the right of false thought. Why shit is obedience and sometimes $\sin$ ? It is impossible to be educated 111 verses (Shabestari, 1382).

It should be noted that Shabestari considers obedience to obedience because it brings the truth closer. It is that thinking in the essence of Quds Jabrut al-Haq leads the seeker astray. Therefore, according to Golshan Raz, Thinking is of two types: permissible thinking and illegitimate thinking (Al-Haji,: 2002) 76 In other places of Golshan, the secret of Shabestari is thinking. And thinking in the soul (ibid .: 166). However, according to various reports (Same, 143)

From Golshan, the secret of thinking is hierarchical. These different levels are: intuitive thinking and reasoning thinking. Argumentation is a mental matter arising from the act of thinking or reasoning, while intuitive thinking has a transcendent origin in mystics. It originates from the Absolute, ie God or the Guardian of God. And it has skeptical levels. The idea prevails that man also has a single identity that while being simple has different authorities and levels, so according to various reports, Golshan Raz corresponds to every level of thinking in human existence with a level of existence and existence, so we can say That Man has the same level of existence in every level of thinking, and his world is in fact the same as his way of thinking and perceiving.

Therefore, it can be said that in Sheikh Mahmoud's thought, thinking is as existence. Accordingly, in Golshan Raz says:

To know that God has hidden secrets in his soul and body

Beyond reason, man is like fire in stone and iron

In the description and analysis of the above verses, it should be noted that Shabestari in Golshan considers the secret of human thought to contain two types, one is intellect and rational protest, and the other is beyond intellect and French wisdom, which is the inner burning and desire through which man is able. It will be to understand the wonders and wonders of the world and the hidden secrets.

The evidence is immersed in the evidence. (Al-Haji,: 1381) 351

\section{6 bit 1382:}

He freed you from his existence (Shabestari, by the light of both worlds became enlightened

If light enters you because this stone and iron fell together

(Shabestari,: 2003) 96-98 (Ground et al.,) 1988

Shabestari also says:

But I do not know the truth, nor do I know how to know him

How did he know last? (Al-Haji,: 1385) 91-93 
The emergence of the sentence of objects is anti-choo, the absence of the essence of the right is not anti-counterpart, it is possible from the obligatory example

Therefore, the formula of contradiction in the world of creation, although it is one of the basic ways in recognizing material creatures and beings, is one of the obstacles in recognizing the Supreme Being and does not lead us to knowledge. (Montazeri et al., 2011) One of the existing ways to reach the knowledge of the Supreme Being is the Supreme Being, thinking and contemplation. This issue has also been approved and recommended in Islamic culture, and man has always been instructed to ponder over how to create creatures in order to realize the greatness of the Creator. The importance of this matter is such that Shabestari started the Golshan-e-Raz system by referring to it and praising God for giving this blessing to the creatures.

\section{Thanked:}

In the name of the one who taught the soul to think, he lit the lamp of the heart to the light of the soul (Al-Haji,: 1385) 1

Rumi also considers the principle of human existence as the power of thought and thought and believes that man is worthless without this power:

Man is vision and the rest is skin. Vision is that vision is a friend. (Astalami,: 1369) 1/14161 (Montazeri and others,.) 1390 According to mystics, the right thought is a thought that is purified from the pure, pure and special by the people of the Almighty. On this basis, they praise the single thought and believe that in addition to Abstraction is another condition of thinking that is accompanied by divine affirmations.

Because without the influence of his right and power, our potential thought will not become. On this basis, Rumi considers thought as the product of the manifestation of his transcendence and affirmation, and what is important for him is to go beyond the actual form of thought and pay attention to its potential interior. .) 1/ 1144-47 (Of course, thinking and its role in achieving knowledge after observing the condition of abstraction and confirmation of the Supreme Being, is correct and logical if it is in the essence of creatures and in the manifestations of creation, otherwise thinking in the essence of truth It is not worthy and it is a sin. Because

The level of essence is the status of silence and human understanding and intellect are unable to comprehend it, so the advice of mystics when with divine conditions is to avoid thinking in essence. Prohibition has a guiding aspect here, which means that this prohibition is to make it known that such a thing is impossible. (Kakaei,: 1385) 278 This matter is derived from the words of the Prophet (PBUH) who said: Think about the people And thinking in the essence of the people. (Ajloni,: 1351.) 311 Shabestari says:

In the case of thinking, it is a condition of the way, but in the essence, the pure right is a sin (AlHajiji,: 1385) 112

He further states the reasons for the ineffectiveness of thinking in the essence of the Supreme Being in the following cases:

A) There is no reason why the essence of truth is old and now disabled:

It was in the essence of the right of false thought that it was impossible to get pure education (ibid.) 113

Rumi has the same opinion and says: 
You are not next to a thought, it is not related to a disability because of a cause

B) Manifestation of truth in plurals: Because the verses are clarified from the essence, his essence is not clarified from the verses

The whole world is in his light, find where he is from the obvious world (Elahi,: 1385) 114

C) Purification of the essence of the Supreme Being:

There is no light in the essence, the manifestations of which are the glorious shadows of the Almighty. According to the principle of thinking in the horizons of the seeker, he should reflect on the validity of the heavens and the association and the stages of their journey, as well as the effects that reach them from the lower world to perfection.

The power of the Supreme Being and the order of the world system should be revealed and the truth should be achieved. Shabestari says: Do not be trapped in the elements and nature, go out and look at the industries

Think in the creation of the heavens that you will be right in the verses until you are praised (Ibid., 210-11 (quoted by Montazeri and others,) 1390

He also states in verses (217-7) that thinking in the horizons makes us realize that creation is not without reason and there is wisdom in the creation of every creature. The creation of the heavens and the earth, and the difference between the night and the day, the bodies of the guardians of the world. (Al-Imran,.) 190 According to the principle of thinking in the soul and soul of man, The principle of the soul can be guided to the names and attributes of truth and to truth and knowledge

Take a good look at your mother who became a father or a mother You see the world head on, you see everything that comes to an end In the end, the soul of Adam became a parasite of his nature, both worlds Does not the ultimate cause eventually appear in its essence?

(Al-Haji,: 1385) 259-62 (Montazeri and others,) 1390

Conclusion It is difficult to study the mystical themes in the two great works of Masnavi and Golshan Raz and to summarize the large number of themes in a short article. The mystical themes used in Masnavi and Golshan Raz are many and tens of pages can be written about each theme. Just listing your topic titles is the size of an article. in this

What are the themes of Masnavi Manavi and Golshan Raz? It can be said that themes such as love, manifestation of truth, repentance, sincerity, thinking, etc. are jointly expressed in two works. According to Feyz Kashani, if one wants to research Rumi's mystical thoughts, perhaps the best way is to analyze the generalities of the sun. But if the aim is to know his perceptions of life and religion, the study of his sonnets will not yield any results. For this purpose, Masnavi is a better choice. Regarding the way of expressing mystical issues in Masnavi, one can get acquainted with Rumi's mystical thoughts through mystical themes. Of course, the interpretation of verses and the understanding of each researcher may be different from what Rumi considers as a mystic. In the interpretations of Rumi's verses or themes in various works, including in this article, there is a corner of the interpretations of different scholars and writers. Shabestari is also very different from other mystics in the themes he brings in his poems does not have.

\section{References}

Forouzanfar, 1998, Masnavi. 
Shabestari, Sheikh Mahmoud, 2003, Golshan Raz Divan.

Atminani, Abbas, (2010), Self-belief, not self-defeat, Golshan Raz Al-Houri's study and comparison with

Golshan Raz Shabestari, Persian Language and Literature Quarterly, First Year No. 3, Summer 2010

Basiripour, Ali, another commentary on Golshan Raz entitled Hadiqah Al-Maaref by Shojauddin Karbalali, Bustan Magazine

Shiraz University, Volume 1, Number 2, Consecutive 1/56, Winter 2009-2015 Zanjani Fall, Faezeh 1389. First, .1390

Tohidian, Rajab, Khadivar, Hadi, (2010), Intuitive and argumentative knowledge in Golshan Raz by Sheikh Mahmoud Shabestari, Scientific and general quarterly of Persian language and literature, literature and mysticism.

Jafari, Hassan, (2007), the manifestation of right in the levels of existence from Rumi's point of view, philosophical researches, number twelve,Autumn and winter.86

Khodavardi Abbaszadeh, (2012), Taherloo, Haniyeh, The Manifestation of Love in Mowlana Poems, Specialized Quarterly of Islamic Mysticism,Year 9, No. 36 Summer. 9-92 Rahimian, Saeed,.) 1387. Faculty of Literature and Humanities, University of Tabriz, year 51, spring and summer 87, serial number .204

Sobhani, Tawfiq (2002), Generalities of Shams Tabrizi, Qatreh Publications, Didavar Print, First Edition, Volume 2

Radial, owner. Hosseininia, Seyed Mohammad Reza, Pakzad, Mehri, (1397), levels of behavior from the perspective of Attar and Shabestari with

Rely on the logic of the bird andGolshan Raz. Quarterly Journal of Mystical and Mythological Literature, Volume 14, Number 51, Summer.97

Shoaei, Malik, (2012), Shabestari and the Thought of the Unity of Existence in Golshan Raz, Quarterly Journal of Belief Research

Kalmi, Second Year, No. 8, Winter 2012

Sharifpour, Enayatullah, Movahedi, Narges, A Study of Mystical Themes in the Poetry of Sacred Defense, Journal of Sustainability Literature,First year, first issue, autumn. 1388

Shahbazi, Iraj, (2016), Hidden Appearance, Rozaneh Publications, First Edition, 2016 - 15 Ground, Saeed, Toby, Mazaher Ahmad, (2016), The Status of Thought and Intuition in Golshan Raz and Mahayana Sutras, Quarterly

Philosophical Research, Volume 12, Number 25, Winter 1397-16 Faridi, Maryam, Tadayon, Mehdi, Manifestation of Unity in Masnavi Mowlana and Taieh Ibn Fariz, Journal of Research in Mystical Literature(Gohar Goya), eighth year, first issue, 26 consecutive, spring and summer. 2014

Faghihi, Hossein, Nazari Nokandeh, Nayreh, 2006, Mystical Themes in Saeb Ghazals, BiQuarterly Journal of Language Research and Persian literature, number ten, spring and summer. 2008

Farahmand, Mohammad, (2012), Sultanzadeh Monafi, Maryam, the degree of compatibility and compatibility of mystical subjects with science in

Golshan Raz Sheikh Mahmoud Shabestari, Islamic Mysticism Quarterly, Eleventh Year, No. 42

Fazilat, Mahmoud, (2008), the levels of existence in Golshan Raz Shabestari, Bahar Adab Quarterly, first year, second issue, Winter .87

Abdollahpour, Ahmad, 1397, a look at the common themes of Maulana Jalaluddin Mohammad Balkhi and Shah Abdul Latif 
Abbasi Montazeri, Lily, Farhadi, Nawazahl, (2011), A Study of the Principle of Knowledge and Theology from the Viewpoint of Mowlana in

Masnavi and its comparison with Shabestari worldview in Golshan Raz, Islamic Mysticism Quarterly, Year 9,No. 35, Spring.92

Aghdaei, Touraj, Golshan Raz Aesthetics, Quarterly Journal of Mystical Literature and Mythology, Year 6, No. 18,Spring .89

Latifi, Abdolhossein, Introduction and Critique of Golshan Raz Shabestari Prominent Explanations, (2016), Islamic Mysticism Quarterly,

Sixteenth Year, No. 61, Fall.98

Arabic, Farshad, (Bita), Manifestation of Quran and Hadith in Golshan Raz by Sheikh Mahmoud Shabestari Examination of Evidence from Adaptation,

Guarantee and Hint, Quarterly Journal of Persian Language and Literature, Literature and Mysticism.

Forouzanfar, Badi-ol-Zaman (1398), Generalities of Shams Tabrizi, First Office, Ayandeh Danesh Publications, First Edition 